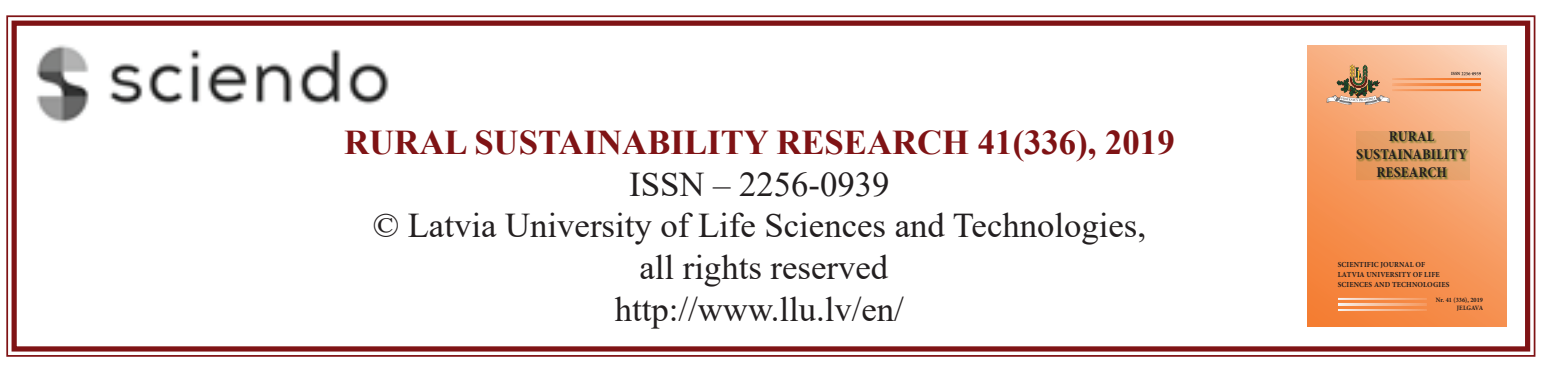

\title{
Food Safety Challenges in the Tourism Processes
}

\author{
*Martin Balazs Zsarnoczky' ${ }^{1}$, Fanni Zsarnoczky-Dulhazi², Gogo Fredrick Collins Adol' \\ Mariusz Barczak ${ }^{4}$, Lorant Denes David ${ }^{5}$ \\ Kodolanyi Janos University ${ }^{1}$, Budapest, Hungary \\ University of Physical Education ${ }^{2}$, Budapest, Hungary \\ Szent Istvan University ${ }^{3}$, Gödöllö, Hungary \\ WSG University of Bydgoszcz ${ }^{4}$, Bydgoszcz, Poland \\ Constantine the Philosopher University in $\mathrm{Nitra}^{5}$, Nitra, Slovakia
}

\begin{abstract}
The modern food industry is among the key partners of today's global tourism. As part of the tourism processes, tourists buy and consume local food in the local catering facilities. Furthermore, tourists are usually willing to try out gastronomy specialties during their travels. Food safety is important for tourists although it is not always part of their conscious behavior in the destination. Food safety standards are regulated by international contracts based on the analysis of more half a century's experiences. Within processes related to the changes in the external environment, there are emerging issues - although in different intensity - like chemical and microbiological contamination or food terrorism. Due to the immense number of participants in tourism, it is of key importance to raise awareness of threats like food decay, infections and other negative impacts, because food safety if a basic need in all tourism destinations. The amount of waste food is increasing dramatically at a global scale. The study will introduce the findings of a food safety research in Hungary, providing useful knowledge to all stakeholders of the tourism industry.
\end{abstract}

Key words: tourism, food safety, food-related risks, food waste, food terrorism.

\section{Introduction}

Tourism is a rapidly growing industry, which has to face many challenges during its various processes. Besides the most common topics of sustainability and climate change, another important aspect of the industry: food safety seems to be neglected, despite the fact that sustainable food supply and risk-free food safety are closely related to each other.

Tourism-related businesses vary on a wide scale in terms of their different demands related to food production and use. In parallel with the emergence of innovative product development, the traditional food industry is also challenged by the release and production of 'novel foods'. Tourism processes and activities related to food consumption exist in close connection.

In general, local people are just as much consumers of local food as tourists; therefore, the relationship and interaction between food and safety need to be clarified. Firstly, food can be considered safe when it is produced and processed properly and in accordance with the technological standards, in order to avoid the possibility that the food can cause any harm to human health (Rodler, 2008). Secondly, it is an important aspect of food safety that regardless of the appropriate technologies, there is always a risk that the raw material of the food contains undetected contaminants or other pathogens. Based on these two notions, we can talk about the scope of food safety and food that is as safe as possible.

\section{Materials and Methods}

Safety issues related to food can be best identified in a framework of efforts taken towards safety. When talking about preserving human health, we must take into account the environmental impacts caused by

1 Novel' foods are foods, or ingredients, which, in the past, were not significantly used for human consumption. In the EU, the legal definition is that they were not used before 1997. 2015/2283 EU.

\footnotetext{
* Corresponding Author's email: martin@kodolanyi.hu
} 
one's lifestyle. The circumstances of optimal food consumption behavior are largely affected by the economic, physical, social and cultural environment. The everyday operation of the human body requires proper food that guarantees health and helps to avoid diseases and the malfunction of the organs. Our research focused on the possible food-related risks created by the expansion of the tourism industry.

A questionnaire survey was carried out in two focus participants groups of 120 people: local people and tourists, in order to analyze their knowledge and experience about food safety during their holiday. Based on the results of the questionnaires, the significant differences were summarized in the form of general statements. The timeliness of the topic and the expected results suggest the possibility of further researches in different directions, because of the increasing attention towards the creation of safe processes.

\section{Results and Discussions}

There are a vast number of standards and regulations related to food safety around the world. Although these legal instructions may vary from region to region, they all aim towards a common objective: to guarantee quality and avoid certain risks. The general food safety regulations are based on the threats identified by the previous risk assessment processes. According to the definition of World Health Organization in 2014, food safety means that the consumption of food will not cause health conditions. The definition of health condition is difficult to describe, because the possible symptoms and risks may vary from person to person. Therefore, it is more useful to focus on the possible threats and aim to minimize the possibilities of their creation.

The four most important threats to food safety are:

- Biological threats: the presence and spread of pathogens;

- Chemical threats: the presence of toxic components

- Physical threats: the presence of foreign bodies/components

- Consequences of natural disasters.

\section{Re-thinking the concept of safe food}

The joint international efforts towards food safety date back more than half a century. The unified standards of food safety were laid down by the World Health Organization and the Food and Agriculture Organization in the 1960s. Since its foundation, the Codex Alimentarius Commission has established more than 40 sub-committees that are all working on the harmonization of the regulations in the different fields related to food and food safety. The guidelines set out in the Codex are among the most important policies of the EU. To provide appropriate information for a wide audience, several information documents were created. Guides like the Green Paper ${ }^{2}$, the White Paper on Food Safety, or the 178/2002 European Commission Regulation ${ }^{4}$ provide detailed information on food legislation and food safety issues.

The issues related to the contamination of foods and food processing aids is closely related to food safety. During food production and processing, several impacts, manipulations and reactions might occur, regardless of the technological processes or the cleanliness of the environment. Due to the fact that in today's industrial agriculture, the chemical-free state of the soil cannot be guaranteed, food and food materials might get contaminated at the earliest stage. Furthermore, as a consequence of modern animal husbandry, the majority of animal products will contain residues of antibiotics or absorbed chemicals, with only their maximum amount regulated by the law.

Climate change has both direct and indirect impacts in the different regions, also affecting food production, food safety and public health processes (Zsarnoczky, 2016). Global warming impacts food safety in several ways. Besides the dramatic expansion of chemical, microbiological contaminants, the fast spreading of various pests poses a serious challenge to agricultural professionals. Beyond the intensive growth of insect populations, the overgrowth of nonindigenous plants and weeds also threats the local ecosystems seriously.

Local producers play an important role in today's 'from farm to fork' initiative; however, we also have to take into account the negative environmental impacts of producing and distributing mass-produced food. It is quite possible that - due to the impact of climate change - today's regional foods will have to be produced in the same way but in a different region in the near future. The solution for the longterm sustainability of local food production requires technological development, the use of renewable technologies and the openness towards the production of non-traditional - but constantly available - types of food (Zsarnoczky, 2018a).

\section{Challenges related to food consumption}

One of the greatest challenges regarding sustainable food safety is the successful management of the increasing amount of waste produced by the

\footnotetext{
http://eur-lex.europa.eu/legal-content/EN/TXT/HTML/?uri=CELEX:52014DC0464\&from=en

3 https://eur-lex.europa.eu/legal-content/en/TXT/?uri=CELEX\%3A51999DC0719

4 http://eur-lex.europa.eu/legal-content/EN/TXT/HTML/?uri=CELEX:32002R0178\&from=EN
} 
food industry and tourism. According to the report published by Food and Agriculture Organization of the United Nations in 2018, around one third of the total produced food (approximately 1.3 billion |tons) end up as waste, while at the same time, almost 800 million people suffer from malnutrition or lack of food. The implementation of food franchise chains and challenges of food distribution - as a consequence of further population growth - may not only create risks, but can also lead to dissatisfaction, easily causing local conflicts (Parfitt, Barthel \& Macnaughton, 2010).

Food waste is a multi-dimensional challenge: infrastructural deficiencies, insufficient knowledge on handling, and the large scale waste of food materials all contribute to the problem. The vast majority of food waste is created in households (Bódi \& Kasza, 2015). Wasting food is an unsustainable process because food consumption motivations are created by the independent behavior of individuals (Horváth, Fürediné-Kovács \& Fodor, 2005). In the case of household food waste, proper training and education on the environmental aspects could largely contribute to the lessening of waste.

Food wasting is also impacted by several other factors. Impacts like emotional drives, subjective experiences, curiosity or gastronomy traditions can all affect the decision making process regarding food consumption (Zsarnoczky, 2018b), similarly to ethical and/or religious factors. In the case of tourism, the greatest challenge is the intention to be able to satisfy all possible needs with high quality services, should they arise at any time.

Besides the negative impacts of wasting food, another serious challenge is the prevention of food terrorism. Today's food chains are an ideal possible target for terrorists (Lakner, Kasza \& Ózsvári, 2012). The stakeholders of the food industry suggest that there are several vulnerable points in the infrastructure of food chains. One of the problems is that because of the concentration of production locations, food materials are produced and distributed in large quantities within the borders on the Union's market, and also exported from third countries (Figure 1.). Due to the concentrated production and the highly effective infrastructure, food products reach the market in a very short time.

Even one contaminated component among the raw materials is enough to pollute the whole production batch. A possible solution for that could be if, instead of concentrated mass production, the food would be manufactured by smaller regional producers - in

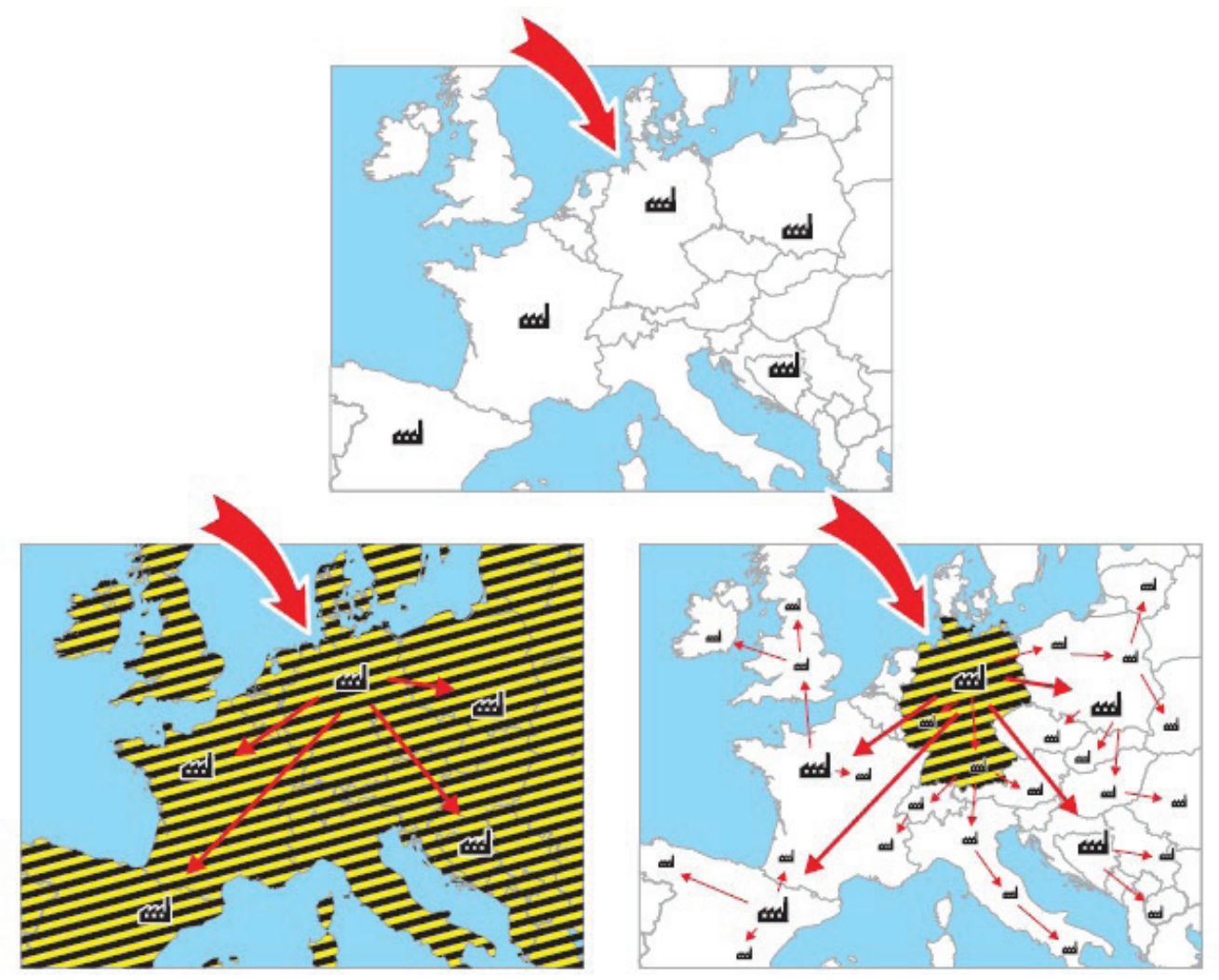

Figure 1. The direction of external food safety threats.

Source: (Zsarnoczky, 2018b). 


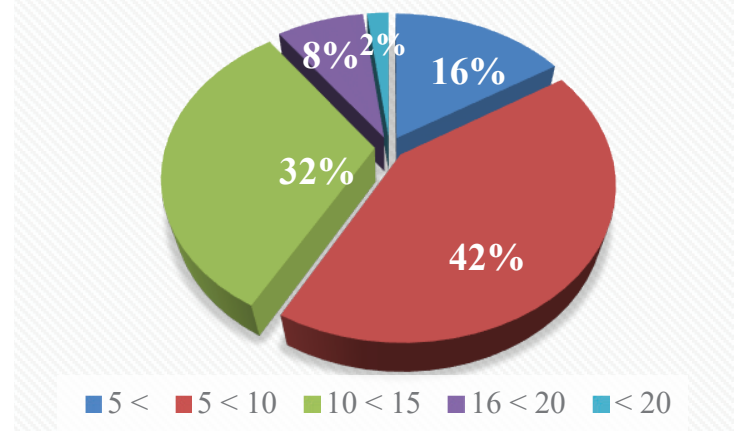

Figure 2. Average frequency of visiting catering facilities during on holiday in Hungary.

Source: Own edition.

this case, the possible problems could be localized and kept in a quarantine. The often insufficient use of water represent another serious threat. The different processes and phases of food production require a huge amount of water. If the water used for the production is not clean, all the produced good will be contaminated, too. Despite the risk of crosscontamination, drinking water is still not considered as foodstuff in many countries, seriously risking the safety of the food production processes. Trust is the core element of food consumption, and even the smallest problem can lead to a situation where consumers stop buying the products completely.

Today, mass produced food can reach basically any corner of the world within hours after production. In the free market competition, all safety margins are considered as a possible risk. In the global market, participating countries can buy and sell almost any product or services, making it extremely difficult to identify all possible risk factors. Multinational companies and international service exporters stand for the principles of commerce based on value-formoney competition; however, even they have never denied the existence of possible threats. As of today, there are no public guidelines neither on the action plans in case of a possible large-scale food poisoning or food-related diseases, nor on the principles of liabilities.

Food safety is not only threatened by terrorism; as a result of inappropriate technological processes, the shelf life of the products can be shortened, possibly resulting in massive infections of poisoning. Food-related epidemics, most commonly caused by Salmonella or Campylobacter may cause serious harm in tourism as well (Zsarnoczky, 2018b).

During our research, we have conducted a questionnaire survey with snowball sampling method in Budapest, asking the respondents about their knowledge and experience on food safety. The snowball sampling method is widely used in researches related to sociology, because the researchers could access many hidden processes and habits. Also, in our research the sample members were selected from tourist's sample frame and likely the sample members are subject to less biases. During the research it was important to gain access and document the cooperation of subjects is trust, even the interviewers acted in good faith and establish good working relationship with the focus groups. Obvoiusly, the snowball sampling method does not require complex planning and the resources required is considerably smaller in comparison to other sampling methods.

During the analysis, special emphasis was put on the difference between the opinions of the 2 consumer groups who are the tourists and the local citizens. The analysis and assessment of the questionnaires resulted in the following findings. Objective factors according to the questionnaires:

- Number of fully completed questionnaires: $104,87 \%$ of the total number of questionnaires taken (120).

- Gender distribution of respondents: 58\% female, $42 \%$ male.

- Ratio of tourists among the respondents: $51 \%$ tourists, $49 \%$ local citizens.

- Sending area of tourists (1-5): Szeged, Györ, Kecskemét, Gyöngyös, Debrecen (all cities are located in Hungary).

- Age of respondents (years): 51-64 (38\%), 36-50 (24\%), 21-35 (20\%), 6-20 (14\%) 75-84 $(4 \%)$.

- Educational level of respondents: $\mathrm{PhD}$ or equivalent level $2 \%$, higher education degree $30 \%$, secondary school certificate $26 \%$, secondary VET certificate $22 \%$, primary education $18 \%$, no finished education $2 \%$.

- Marital status of respondents: married 56\%, divorced and in a relationship $20 \%$, single in a relationship $13 \%$, single $9 \%$, widow(er) $2 \%$.

- Travelling habits of respondent tourists: at least one domestic travel per year (48\%), at least 2 domestic travels per year $(30 \%)$, at 
least 3 domestic travels per year (12\%), at least 4 domestic travels per year $(8 \%), 5$ or more than 5 domestic travels per year $(2 \%)$.

- Number of food product types bought at local markets and/or fairs whilst travelling: one type of food (28\%), 2 types of food (40\%), 3 types of food $(22 \%), 4$ types of food $(8 \%), 5$ or more types of food (2\%).

- Number of visits to local catering facilities: $5<(16 \%)$, between 5 and10 (42\%), between 10 and $15(32 \%)$, between 16 and $20(8 \%)$ more than 20 (2\%) (Fig.2).

The findings of the questionnaires resulted in the following general statements:

- local people and tourist have different priorities related to food safety,

- due to their lack of knowledge on local habits and production processes, tourists tend to distrust local products,

- tourist tend to trust international franchise food chains, due to food safety issues,

- when buying food during their travels, tourist tend to prefer international brands,

- tourists are willing to try specific food products upon recommendation,

- tourist consider drinking water as food during their travels, and access to drinking water is a priority for them,

- the appearance and cleanness of the stores and the wide variety of products are priorities for local citizens,

- at 8 occasions out of 10 , local citizens tend to buy food based on the more favorable price,

- local citizens trust in local producers more than in international brands,

- local citizens are willing to buy the own brands of local food stores and are satisfied with the quality.

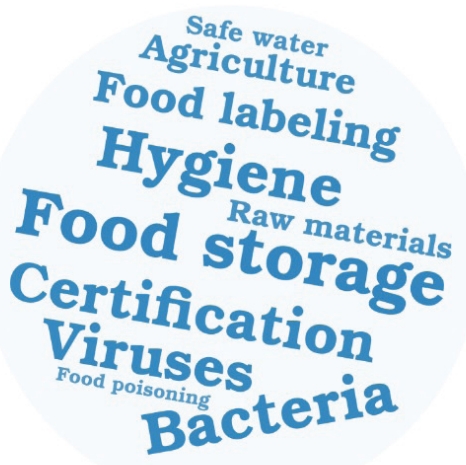

Figure 3. Priorities for local citizens related to food safety.

Source: Own edition.

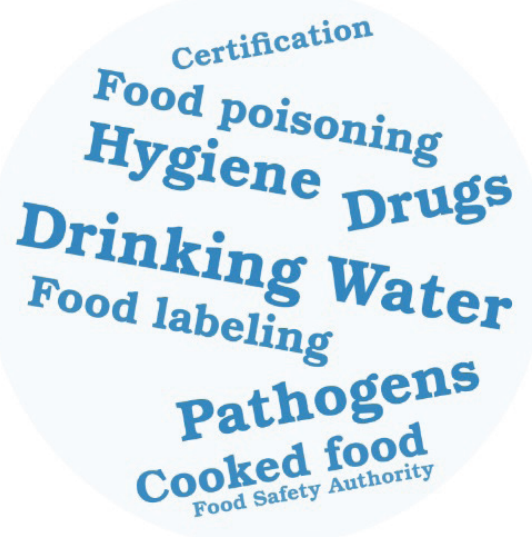

Figure 4. Priorities for tourists related to food safety. Source: Own edition.

During the analysis of the questionnaires, we have collected the terms related to food safety. The answers of the respondents are summarized in the word clouds in Figure 3 and in Figure 4. The word clouds clearly show the priorities of the two groups. The world cloud of Fig. 3. contains the priorities of the local people; the terms most often mentioned by tourists are collected on the Fig. 4 . The findings of the research clearly show that the food safety priorities of local people and tourists are different. A possible explanation for that is local people know and therefore, trust - local products more than tourist, who tend to opt for international brands and franchise products during their travels. This phenomenon is further strengthened by the trend that local producers generally do not target tourist with their products.

\section{Conclusions}

The concept of food safety has different meanings for the stakeholders of tourism. In the food industry, the most important challenges are related to the various limit values regulated by international standards and laws. The changes in the environment had resulted in the emergence of resistant GMO foods, the contamination of the food chain with pollutants and foreign bodies, and damages caused by non-indigenous plants, animals and insects. Although national public health organizations usually priorities the issues of prevention, localization and the safety of supply chains, their top priorities should be the general level of public health and guaranteeing general food safety for the public in Hungary.

In the near future, the food industry will have to face challenges imposed by factors like global concentration, the rise of diversified food chains, the decline of local traditions, the emergence of new types of consumer demands and the increased rate of 
processed goods among food products. As a result of mass food production, the industry also have to face the negative impacts of dramatically increasing food waste.

The safety of food production and supply, where the threat of food terrorism is minimized is a top priority both for tourism stakeholders and citizens. Safety is a key issue in all aspects of tourism, including all foodrelated areas as well. As for local citizens and tourist, the priorities related to food safety are different. This trend might be changed if the local producers would use seasonal strategic marketing tools to gain the trust of tourist for their food products.

\section{References}

1. Bodi, B. \& Kasza, Gy. (2015). Demográfiai tényezők hatása a fogyasztói élelmiszerpazarlásra - Élelmiszervizsgálati közlemények (Impact of demographic factors on consumer food waste - Food inspection announcements). Középpontban 2015 (3), 33-41. (in Hungarian)

2. Food and Agriculture Organization of the United Nations (2018). Food loss and waste and right to adequate food: Making the connection. Retrieved January 26, 2019, from http:/www. fao.org/3/ca1397en/ CA1397EN.pdf

3. Horvath, A., Furedine-Kovacs, A. \& Fodor, M. (2005). Az értékrend hatása a táplálkozásra (The effect of the value system on nutrition). Élelmiszer Táplálkozás és Marketing II (12), 7374. (in Hungarian)

4. Lakner, Z., Kasza, Gy. \& Ózsvári, L. (2012). Bioterrorizmus története és jelentősége (History and significance of bioterrorism) Magyar Állatorvosok Lapja 134 (7), 433-441. (in Hungarian)

5. Parfitt, J., Barthel, M. \& Macnaughton, S. (2010). Food waste within food supply chains: quantification and potential for change to 2050. Philosophical Transactions of The Royal Society B. 365, 3065-3081.

6. Rodler, I. (2008). A táplálkozás és az életmód szerepe a rákbetegség kialakulásában (The role of nutrition and lifestyle in the development of cancer). Egészségtudomány 54 (2), 14-21. (in Hungarian)

7. World Health Organization (2014). Advancing food safety initiatives: strategic plan for food safety including foodborne zoonoses p. 2013-2022. Retrieved January 25, 2019, from http://apps.who.int/ iris/ bitstream/10665/101542/1/9789241506281_ eng.pdf?ua=1

8. Zsarnoczky, M. (2016). The Future of Sustainable Rural Tourism Development - The Impacts of Climate Change. Annals of The Polish Association of Agricultural and Agribusiness Economists 19 (3), 337-344.

9. Zsarnoczky, M. (2018a). The Importance of Tradition and Folk Customs in Gastro-Tourism. Intercathedra 34 (1), 95-102.

10. Zsarnoczky, M. (2018b). Az élelmiszerbiztonság és a turizmus összefüggései az Európai Unióban (The relationship between food safety and tourism in the European Union). In EMOK XXIV. International Conference: Conference proceeding, 27-28 August 2018 (pp. 744-754). Univerzita J. Selyeho, Komárno, Slovakia. 